\title{
Açai seedling production: effect of substrates and seeds size on germination and growth of seedlings
}

Oscar J. Smiderle1; Vanuza X. Silva2; Edvan A. Chagas1; Aline G. Souza1; Maria I.G. Ribeiro2, Pollyana C. Chagas2, Olisson M. Souza2

1Empresa Brasileira de Pesquisa Agropecuária. Boa Vista-RR, Brasil. *Corresponding author

E-mail: edvan.chagas@embrapa.br*,oscar.smiderle@embrapa.br

2Universidade Federal de Roraima. Boa Vista-RR, Brasil.

E-mail:vanuzzaxavier@gmail.com, alineufla@hotmail.com, bel_s.g@hotmail.com, pollyana.chagas@ufrr.br,

\section{ABSTRACT}

mesquita_ox@yahoo.com.br

The açaí palm (Euterpe oleracea Mart.) is a tree native to the Amazonia. In some states in the region, growth of the planted area has been observed, but the difficulty in obtaining substrates which are viable for the production of seedlings is high. It was intended in a first step to evaluate the effect of seed size and substrates upon germination and in the second step, to evaluate the initial growth of seedlings of $E$. oleracea on different substrates. The experimental design was a completely randomized design in $2 \times 2$ factorial scheme with four replications at 100 seeds. Germination percentage, percentage of abnormal seedlings, shoot and root length and dry weight of the seedlings were evaluated after 70 days. In the second step, completely randomized design in $9 \times 6$ factorial scheme with five replications with four seedlings/ plot was utilized. At $60,90,120,150,180$ and 210 days after transplanting, shoot height and diameter of the stem of the plant were assessed, number of leaves were determinate at 90,120,150, 180 and 210 dat and at 210 dat, determinations of dry weight of the shoot and root system were conducted. These samples were put in an oven with forced air circulation at $60{ }^{\circ} \mathrm{C}$ for 72 hours. Açaí seeds considered large present greater germination percent as compared with small seeds and the substrate sand provides greater percentage of seed germination. The substrates composed of $75 \%$ (soil+sand) + $25 \%$ manure and with $75 \%$ (soil+sand) $+25 \%$ carbonized rice husk present better development of açai seedlings.

\section{Keywords}

Euterpe olerace, native fruit tree, seedling propagation.

\section{Academic Discipline And Sub-Disciplines}

Agricultural Science; Biology

\section{Council for Innovative Research}

Peer Review Research Publishing System

Journal: JOURNAL OF ADVANCES IN AGRICULTURE

Vol .4, No. 1

www.cirjaa.com, jaaeditor@gmail.com 


\section{INTRODUCTION}

The açai palm (Euterpe oleracea Mart.), a palmaceae native to Amazonia, has stood out economically for the market potential of its products represented mainly by the palm heart and by the juice extracted of the fruit [3].

Brazilian palm heart production reached 132,105 tons in 1985, the state of Pará accounting for $88.5 \%$ of that supply; in 1994, the Brazilian production fell to 22,500 tons due, probably, to the depletion of the native reserves, to the restriction of several countries to the product originating from gathering and to the redirecting of the utilization of açaí for pulp extraction, which is a product with an expanding demand even on the international market [18].

The most effective way of reintroducing those species in the environment with conservation and commercial exploitation purposes is through seeds [23], since the propagation of palms is obtained almost exclusively by means of seeds. Nevertheless, it presents slow, uneven germination and, often, with low percentage, influenced by several factors as the degree of maturation, the presence or not of the pericarp, the time elapsed between harvest and sowing, the temperature of the place, the substrate, the shape, the size and volume of the seed, among others [19].

Research efforts have shown the importance of biometrics in distinguishing genera, species and populations within the same species [11]. Thus, seed specific weight and size among many species are an indicative of their physiological quality, allowing to aid in the understanding of the germination process and characterization of vigor and viability of the crop $[17,21,22,23)$.

Decision on which substrate toes relevant factor for supplying moisture and providing conditions adequate for germination and development of the seedlings [2, 7, 20]. The substrate should present low cost, availability approximately the region of consumption, enough nutrient content for the species utilized, good cation exchange capacity, and relative biological sterility and allow both aeration and retention of moisture supporting the physiological activity of the plant roots [10].

Although, cropping systems of açai are quite investigated, little is known about the growth potential and early development of these species on substrates, particularly on those constituted on the basis of mixtures of byproducts such carbonized rice hulls. The production of açai seedlings is insufficient to meet the market demand, which should provide a significant increase in the production in several states in the Amazon region, chiefly in the state of Roraima. It can be also emphasized that in Roraima, like in other Amazon states, there is no availability of commercial substrates and, when they are found, the price is high due to the transportation costs, which makes it difficult, and lots of times, makes the production of seedlings of high quality and on a large scale unviable.

Thus, the objective in this study was to determine the effect of the seed size and of different substrates on germination and on the early growth of açai seedlings

\section{MATERIALS AND METHODS}

The research was conducted at Embrapa Roraima, utilizing the seed analysis laboratory and the seedling nursery of the fruit cultivation sector, all situated on BR 174, Km 8, Industrial District, under the geographical coordinates of reference $02^{\circ} 45^{\prime} 28^{\prime \prime} \mathrm{N}$ and $60^{\circ} 43^{\prime} 54^{\prime \prime} \mathrm{W}, 90 \mathrm{~m}$ of altitude. Boa Vista lies in the Tropical Climate Zone; the average rainfall is of $1,750 \mathrm{~mm}$ yearly, air temperature of $26.7^{\circ} \mathrm{C}$ and relative humidity of air, $79 \%$ [1].

The açai species utilized was E. oleracea, the seeds of which for formation of the seedlings were taken out of ripe, healthy and good quality fruits, from populations native to the south of the State of Roraima. The fruits had their pulps removed and the seeds washed in running water. After the removal of excess moisture, the seeds were separated by size, obtaining seeds considered large with mass of $85 \mathrm{~g}$ and small with mass of $58 \mathrm{~g}$ for each 100 seeds. Two experiments were conducted at a time. The first step was developed with the purpose of determining the effect of the seed size and of different substrates in the germination of $E$. oleraceae seeds. The experimental design utilized was the completely randomized in $2 \times 2$ factorial scheme with four replications. Each replication was made up of 100 seeds, amounting to 1,600 seeds. The factors under study were: two substrates (cleaned sand and sawdust) and two seed sizes (large and small).

The seeds were placed into plastic bags with a capacity of 1 litre of the substrate corresponding to each treatment. At 70 days from the start of the experiment, the following analyses were conducted: germination percentage (GE, \%); percentage of abnormal seedlings (PA, \%); length of the shoot (CPA, cm) and of the root (CR, cm) and dry mass of the seedlings (MSP, g), the same ones being put separately into identified paper bags, placed into oven with forced air circulation at the temperature of $60^{\circ} \mathrm{C}$ for 72 hours, subsequently weighted in a semi-analytical balance.

The second step was the determination of the early growth of açai seedlings in mixtures of substrates. After germination period, the seedlings before reaching a pair of leaves were selected and transplanted into polyethylene bags $17 \mathrm{~cm}$ high and $12 \mathrm{~cm}$ in diameter, holding a liter of the substrates. The experimental design utilized was the completely randomized in $9 \times 6$ factorial scheme with five replications. Each plot was made up of four seedlings (a plant in each polyethylene bag). The factors under study were nine mixtures of substrates ((T1) sand + soil (3:1 v/v); (T2) commercial substrate (Vivato Plus $^{\odot} 100 \%$ ); (T3) $25 \%$ (soil + sand - T1 ) + 75\% of manure; (T4) $50 \%$ (soil + sand - T1) + 50\% of manure; (T5) $75 \%$ (soil + sand - T1) + $25 \%$ of manure; (T6) $25 \%$ (soil + sand - T1) $+75 \%$ of carbonized rice hull; (T7) $50 \%$ (soil + sand - T1) + $50 \%$ of carbonized rice hull; (T8) $75 \%$ (soil + sand - T1) $+25 \%$ of carbonized rice hull; (T9) $25 \%$ of soil $+25 \%$ sand + $25 \%$ of manure $+25 \%$ of carbonized rice hull) and six evaluation times (60, 90, 120, 150, 180 and 210 days). Both experiments were conducted in the seedling nursery of the fruit cultivation sector. The mincronutrient content (Table 1) of the mixtures of the substrates was determined, according to the methodology of Tedesco [24]. 
Table 1: Results of the micronutrient and chemical analysis of the nine substrates utilized in the initial development of açaí seedlings (Boa Vista-RR, Brasil, 2015)

\section{Micronutrients}

\begin{tabular}{lllllll}
\hline & Zn & Fe & Mn & Cu & B & S \\
\cline { 2 - 7 } & \multicolumn{7}{c}{$\mathbf{m g ~ d m}^{\mathbf{3}}$} & & \\
n1 & 26.66 & 40.93 & 139.03 & 1.06 & 0.58 & 18.82 \\
T2 & 26.94 & 62.34 & 160.22 & 0.56 & 0.72 & 49.14 \\
T3 & 24.44 & 13.50 & 90.94 & 0.64 & 0.78 & 50.68 \\
T4 & 23.49 & 20.25 & 106.97 & 0.78 & 0.78 & 34.91 \\
T5 & 24.34 & 27.86 & 111.23 & 1.03 & 0.67 & 25.85 \\
T6 & 16.50 & 13.51 & 88.56 & 0.30 & 0.48 & 17.15 \\
T7 & 0.76 & 17.99 & 127.27 & 0.56 & 0.56 & 17.70 \\
T8 & 23.34 & 33.50 & 132.31 & 0.78 & 0.40 & 19.40 \\
T9 & 23.10 & 15.13 & 100.54 & 0.69 & 0.64 & 28.07
\end{tabular}

\section{Chemical Analysis of the Substrates}

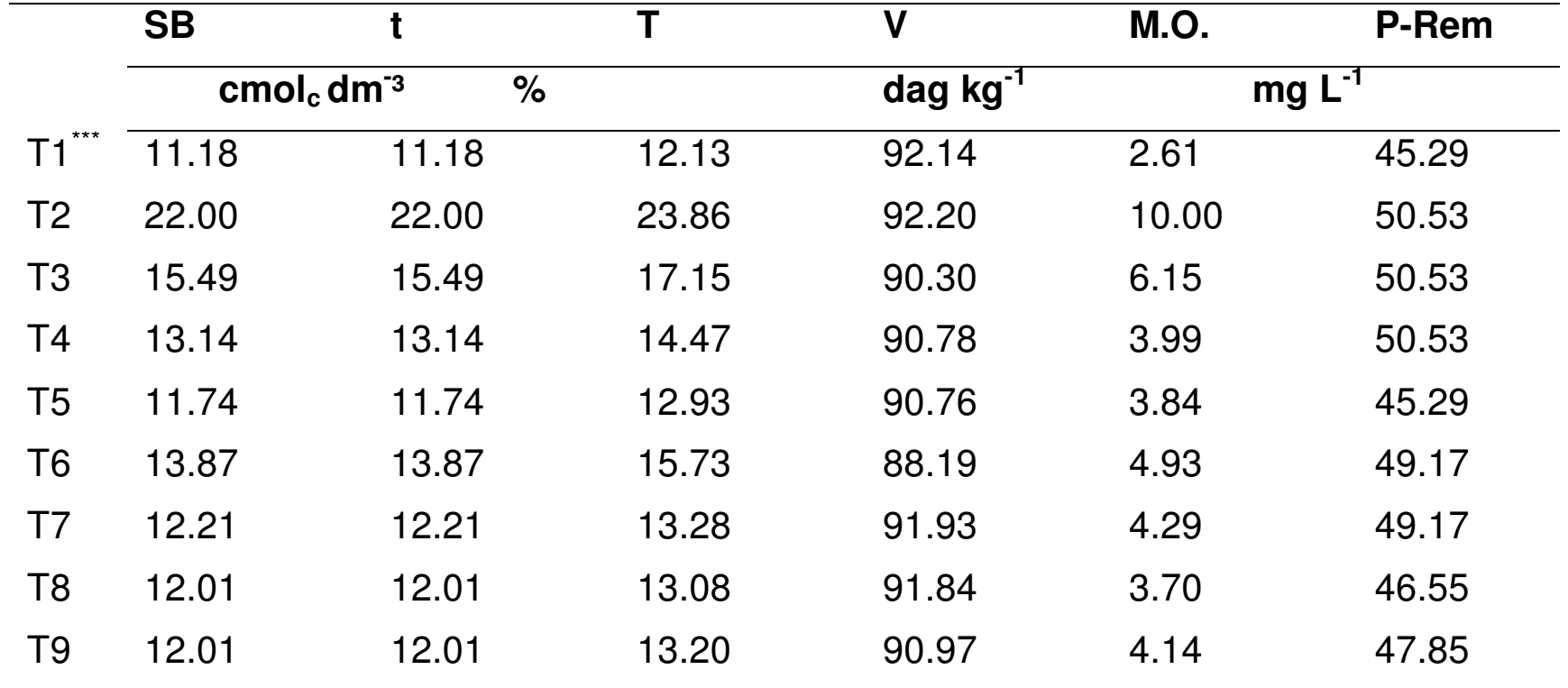

"Zn= zinc; Fe= iron; Mn= manganese; $\mathrm{Cu}=$ copper; $\mathrm{B}=$ boron; $\mathrm{S}=$ sulfur; "SB= sum of bases; $\mathrm{t}=$ effective CEC; $\mathrm{T}=\mathrm{CEC}$ at $\mathrm{pH}_{* x}$ 7.0; $\mathrm{V}=$ basis saturation; $\mathrm{M} . \mathrm{O}=$ organic matter; $\mathrm{P}-\mathrm{rem}=$ soil clay content or value of remaining phosphorus. ${ }^{* *}$ Treatments: ((T1) sand + soil (3:1 v/v); (T2) commercial substrate (Vivato Plus $\left.{ }^{\complement} 100 \%\right)$; (T3) $25 \%$ (soil + sand - T1) + $75 \%$ of manure; (T4) $50 \%$ (soil + sand - T1) $+50 \%$ of manure; (T5) $75 \%$ (soil + sand - T1) $+25 \%$ of manure; (T6) $25 \%$ (soil + sand - T1) $+75 \%$ of carbonized rice hull; (T7) 50\% (soil + sand - T1) $+50 \%$ of carbonized rice hull; (T8) $75 \%$ (soil + sand $-\mathrm{T} 1$ ) $+25 \%$ of carbonized rice hull; (T9) $25 \%$ f soil $+25 \%$ sand $+25 \%$ of manure $+25 \%$ of carbonized rice hull).

The irrigation of the plants on the substrates was conducted mannualy, daily according to the plants' needs. At 60, 90 , $120,150,180$ and 210 days after the transplanting, height of the shoot taken from soil to the plant apex (millimeter ruler) and the diameter (tachymeter) taken at $1 \mathrm{~cm}$ from soil were collected. At 90, 120, 150, 180 and 210 days after transplanting, number of leaves (NF) was evaluated and at 210 days, the analyses of the shoot dry matter (MSPA) and dry matter of the root system (MSR) were undertaken, adopting the same methodology already reported in the first step.

The evaluated variables were submitted to the statistical analysis by the Sisvar statistical program [9], performing the analyses of variance and of regression for the factor time (DAT) and Tukey's test at $5 \%$ of probability.

\section{RESULTS}

Mean values of açai seed germination of presented (Table 2), significant difference between substrates and seed size. 
Table 2: Average values of germination (GE, \%) and of abnormal seedlings (PA, \%) concerning substrates and size of açai seed (Boa Vista- RR, Brasil, 2015)

\begin{tabular}{|c|c|c|}
\hline \multirow[b]{2}{*}{ Size } & Sand & Sawdust \\
\hline & \multicolumn{2}{|c|}{ Germination (\%) } \\
\hline Small & $66.80 \mathrm{bA}$ & $39.80 \quad \mathrm{aB}$ \\
\hline \multirow[t]{2}{*}{ Large } & $92.00 \mathrm{aA}$ & 46.00 \\
\hline & Abno & \\
\hline Small & $4.00 \mathrm{aA}$ & $2.50 \mathrm{aA}$ \\
\hline Large & $1.00 \mathrm{aA}$ & 2.50 \\
\hline
\end{tabular}

In the interaction within the factor substrate saw powder, the small seeds presented root length longer than the large seeds, that length being equal to that obtained by the small seeds on the sand, but it did not influence statistically the results (Table 3). The substrate sawdust provided smaller CPA, regardless of the size of seeds and shorter length of roots obtained from the seeds classified as large.

Table 3: Average values of length of the shoot (CPA) and of the roots (CR) obtained according to substrates and to size of açai seed obtained at 70 dat (Boa Vista- RR, Brasil, 2015)

\begin{tabular}{lllll}
\hline & \multicolumn{3}{c}{ Sand } & Sawdust \\
\cline { 2 - 5 } Size & & & Shoot length $(\mathbf{m m})$ & \\
\hline Small & 36.10 & $\mathrm{aA}$ & 28.73 & $\mathrm{aB}$ \\
Large & 35.57 & $\mathrm{aA}$ & 27.93 & $\mathrm{aB}$ \\
\hline
\end{tabular}

\begin{tabular}{l|llll}
\hline & \multicolumn{5}{c}{ Root lengths $(\mathbf{m m})$} \\
Small & 71.71 & $\mathrm{aA}$ & $63.68 \mathrm{aA}$ \\
Large & 70.50 & $\mathrm{aA}$ & 53.54 & $\mathrm{bB}$ \\
\hline
\end{tabular}

Means followed by the same letter, small in the column and capital in the row do not differ from one another by Tukey's test $(p>0.05)$.

The dry matter of açai seedlings was influenced by the seed size (Table 4), that is, seedlings originated from large seeds presented dry matter of $0.508 \mathrm{~g}$ superior the seedlings originated from small seeds $(0.348 \mathrm{~g})$, showing no influence of the substrates utilized in the work.

Table 4: Average values of dry matter of seedlings (DM) obtained from the substrates and from the size of the açai seed obtained at 70 days (Boa

Vista- RR, Brasil, 2015)

\begin{tabular}{lll}
\hline & Sand & Sawdust \\
\hline Size & \multicolumn{2}{c}{ Dry matter $(\mathbf{g})$} \\
\hline Small & $0.343 \mathrm{bA}$ & $0.354 \mathrm{bA}$ \\
Large & $0.513 \mathrm{aA}$ & $0.504 \mathrm{aA}$
\end{tabular}

Means followed by the same letter, small in the column and capital in the row do not differ from one another by Tukey's test $(p>0.05)$.

In the second study concerning different substrates in seedling development, according to Figure $1 \mathrm{~A}$ and $1 \mathrm{~B}$, the interaction between substrates and evaluation period was significant both for shoot height (APA) and stem diameter (DAC), that is all treatments presented positive linear growth along the evaluating period, one may note that treatment T3 presented the least growth of DAC at 210 days after planting (DAP). 


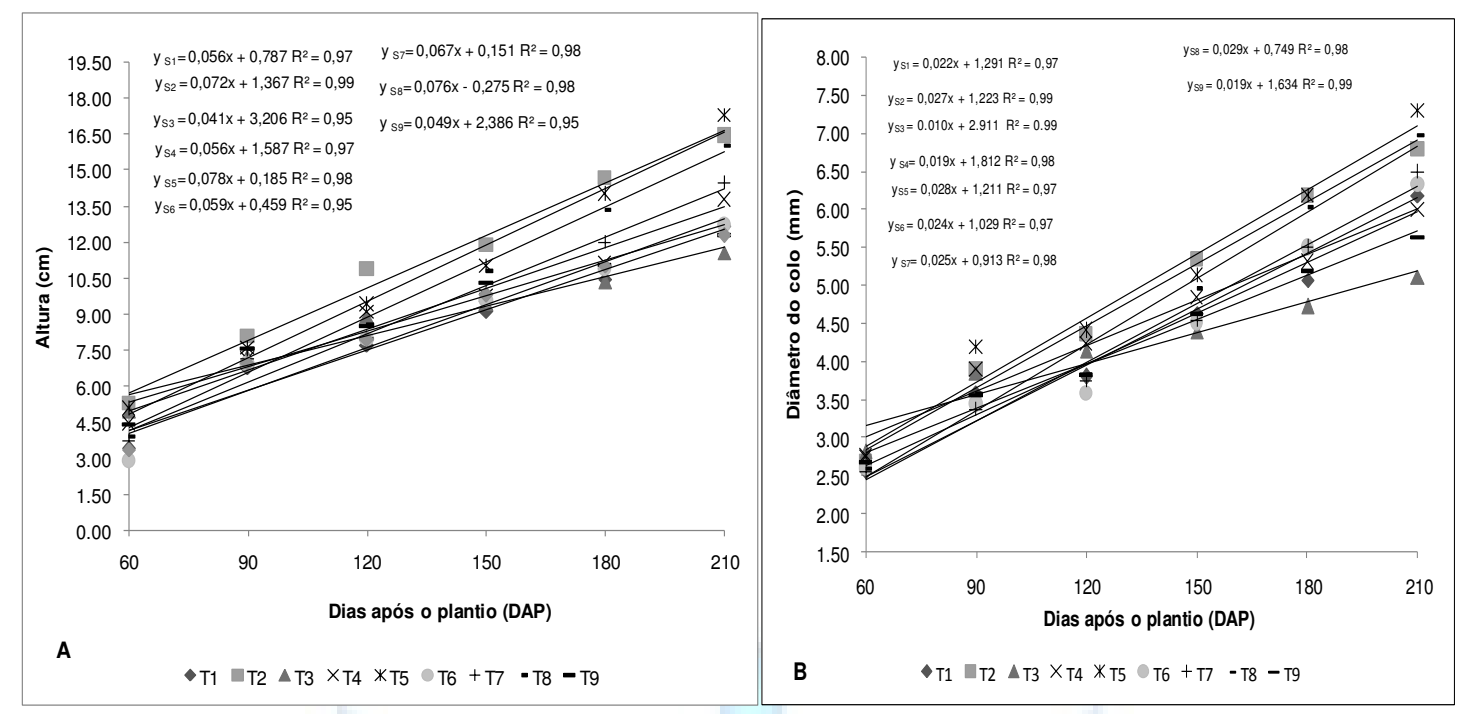

Figure 1: (A) Shoot height (APA) and (B) stem diameter (DAC) obtained on açai seedlings developed on different substrates for 210 days (Boa Vista- RR, Brasil, 2015). $R^{2}$ : Coefficient of determination; the polynomial functions were significant at $1 \%$ by the $F$ test.

In Figure 2, it is observed on açai seedlings developed on different substrates. It was found that there was a linear increase over time estimated for all treatments.

Figure 2: Number of leaves (NF) obtained on açai seedlings developed along 210 days (Boa Vista- RR, Brasil, 2015). $\mathbf{R}^{2}$ : Coefficient of determination; the polynomial functions were significant at $1 \%$ by the $F$ test.

In Table 5, it is observed average values of dry biomass of the shoot (MSPA, g) and of the root (MSR, g) obtained from açai seedlings on nine different substrates.

Table 5: *Average values of dry biomass of the shoot (MSPA, g) and of the root (MSR, g) obtained from açai seedlings on nine different substrates (T1 to T9) at 210 dat (Boa Vista- RR, Brasil, 2015)

\begin{tabular}{llllllllll}
\hline & \multicolumn{7}{c}{ Tratamentos } \\
\cline { 2 - 9 } & T1 & T2 & T3 & T4 & T5 & T6 & T7 & T8 & T9 \\
\hline MSPA & $12,8 \mathrm{abc}$ & $12,9 \mathrm{abc}$ & $2,7 \mathrm{~d}$ & $11,7 \mathrm{bc}$ & $18,1 \mathrm{a}$ & $12,1 \mathrm{bc}$ & $16,0 \mathrm{ab}$ & $17,0 \mathrm{ab}$ & $7,9 \mathrm{~cd}$ \\
MSR & $6,6 \mathrm{ab}$ & $3,5 \mathrm{~cd}$ & $0,6 \mathrm{e}$ & $4,9 \mathrm{bcd}$ & $7,2 \mathrm{ab}$ & $5,8 \mathrm{bc}$ & $6,7 \mathrm{ab}$ & $8,8 \mathrm{a}$ & $2,6 \mathrm{de}$ \\
\hline
\end{tabular}


"Means followed by the same letter in the row did not differ from one another at the level of $5 \%$ of significance by Tukey's test. Coefficient of variation for dry biomass of the shoot, $24.51 \%$ and of $21.40 \%$ for the root. ${ }^{* *}$ Treatments: ((T1) sand + soil (3:1 v/v); (T2) commercial substrate (Vivato Plus ${ }^{\odot} 100 \%$ ); (T3) $25 \%$ (soil + sand - T1) + 75\% of manure; (T4) $50 \%$ (soil + sand - T1) $+50 \%$ of manure; (T5) $75 \%$ (soil + sand - T1) $+25 \%$ of manure; (T6) $25 \%$ (soil + sand - T1) $+75 \%$ of carbonized rice hull; (T7) $50 \%$ (soil + sand - T1) $+50 \%$ of carbonized rice hull; (T8) $75 \%$ (soil + sand - T1) $+25 \%$ of carbonized rice hull; (T9) $25 \%$ of soil $+25 \%$ sand $+25 \%$ of manure $+25 \%$ of carbonized rice hull).

\section{DISCUSSION}

The seeds classified as large presented greater germination (92\%) and low percent of abnormal seedlings (1\%) on the substrate sand. However, when saw dust was utilized as a substrate for germination, the seed size did not show any significant differences both in germination and in the abnormal seedlings (Table 2).

Divergent works were obtained by Vendramin \& Carvalho [25] working with pitanga seed in relation to the mass of the fruit and to the size of the seed, in which the authors obtained greater percent of abnormal seedlings in large seeds.

According to Carvalho \& Nakagawa [6], seed size may be related with the amount of reserves, observing that in large seeds fast synthesis of secondary compounds important to germination occur, greater production of photosynthetic tissue demanded in the growth of the seedlings and increased survival capacity take place under unfavorable conditions.

In a similar way, Lima et al. [15] working with achiote seeds of the cultivar Casca Verde obtained on the substrate sand $81.5 \%$ of germination while in the substrate saw dust only $25 \%$ and greater percent of abnormal seedlings.

The values obtained in the present study corroborate with the ones found by Beckmann-Cavalcante et al. [3], who working with different substrate in the germination of seeds of the juçara and açai palms, found that the substrate sand provide greater germination percentage $73.7 \%$ and $59.0 \%$, respectively.

Silva et al. [22], verifying the influence of the size of the seed upon germination and on the vigor of jackfruit seedlings (Artocarpus heterophyllus Lam), found (CPA) values of $25.99 \mathrm{~cm}$ for seeds classified as small and $31.68 \mathrm{~cm}$ as large not differing significantly from one another among sizes of seeds, corroborating with those of the present study for one same species (Table 3).

In a different way, works conducted by Kleinet al. [14], evaluating different sizes of seeds on emergence and early development of pitanga seedlings (Eugenia uniflora L.) found that the greatest means for shoot and root length were obtained with seeds of large size.

Similar results in Table 4 were obtained by Silva et al. [13], studying characteristics of the seed in relation to its physiological potential and quality of the jackfruit seedlings ( $A$. heterophyllus Lam.), where it was found that the dry matter of seedlings differed significantly because of the size of the seeds. Large seeds provided greater average values of dry matter of seedlings.

Studies conducted by Gama et al. [12] evaluating the effect of different substrates upon germination and vigor of seeds of Euterpe oleracea, found that the greatest values for seedling dry matter were obtained in the substrates sand and vermiculite.

Seedling dry matter is a way of evaluating growth, managing to determine, with precision, the transfer of reserves the seed to the embryonic axis [12], in such a way that the samples with greatest dry matter are considered as of greatest vigor.

Treatments T2, T5 and T8 contributed towards the highest APA and DAC of the seedlings (Figure 1A and 1B). Those treatments were superior to the others, mainly from 120 DAP on and continuing till less 210 DAP. So, the treatments containing greatest percent of soil + sand $(75 \%)$ and highest percent of organic matter $(25 \%$ of manure or carbonized rice hull) presented result similar to the treatment (T2 Vivato Plus $\left.{ }^{\odot} 100 \%\right)$. Martins Filho et al. [16] also found superiority of the substrate $75 \%$ soil $+25 \%$ cattle manure upon stem base diameter $(\mathrm{mm})(\mathrm{DC})$ and shoot height $(\mathrm{cm})($ APA) for peach palm seedlings (Bactris gasipaes).

Brahm et al. [2] working with different substrates upon the initial development of palm trees Euterpe edulis (Mart.) and Roystonea regia (Kunth) obtained, at 240 days, for Caribbean royal palm the best response concerning height $(17.54 \mathrm{~cm})$ and diameter $(8.57 \mathrm{~mm})$ on bush soil/carbonized rice hull $(3: 1)$, standing out superior growth as obtained in the present study.

In contrast, on substrate T3, which contained greater percent of organic matter (75\% manure), presented the lowest values for APA and DAC (Figure $1 \mathrm{~A}$ and $1 \mathrm{~B}$ ). On the other hand, divergent results were obtained by Bentes \& Iriarte Martel [4], where the substrate with $100 \%$ organic soil presented the best values for number of leaves, length and stem base diameter of açai seedlings. That poorer performance found in T3 can be due to the incidence of a disease (or nutrient deficiency) which brought about the death of some plants of that treatment.

According to Filho et al. [10], the substrates with $65 \%$ soil+ $10 \%$ sand $+25 \%$ cattle manure and Plantmax ${ }^{\circledR}+$ osmocote $(5 \mathrm{~g}$ $\mathrm{L}^{-1}$ ) were the ones that promoted the best growth of the species Australian royal palm and peach palm for seedling production. The substrate has great influence in the process of seedling formation, mainly in the initial phases of the seedlings.

Stem base diameter and number of leaves are important aspects in the process of forming palm seedlings and are directly related with the earliness and yield of those plants according to Bovi et al. [5], the diameter being correlated positively with 
the palm heart weight and of the total biomass. That characteristic, plant length as well as stem base diameter and number of leaves should be observed with attention, because shoot height correlates positively with biomass and leaf area [8].

It was found on T4 $(50 \%$ (soil + sand $-\mathrm{T} 1)+50 \%$ of manure) and on T8 $(75 \%$ (soil + sand $-\mathrm{T} 1)+25 \%$ of carbonized rice hull) a tendency of better responses to the variable number of leaves on açai seedling (Figure 2). Again, tendency of poorer results for T3 $(25 \%$ (soil + sand $-\mathrm{T} 1)+75 \%$ of manure (Figure 2 ) was found, in the same way as for the variable height and stem diameter.

The substrates presented significant differences among them as to the chemical composition (Table 1), observing that chemically all substrates were considered fertile due to presenting Base saturation Index higher than $70 \%$.

However, only the result obtained on the seedlings of commercial substrate Vivato Plus ${ }^{\odot}$ (T2) can be explained by its chemical characteristics, because on that substrate the açai seedlings were better in practically all the variables of the chemical analysis, presenting the highest values for macro and micronutrients, in addition to obtaining the greatest sum of bases (SB), cation exchange capacity (effective and total CTC (t) and (T)), greatest content of organic matter and of remaining phosphorus (Table 1 ).

Substrate T3 presented the second best SB, effective and total CTC and considerable contents of macro and micronutrients, containing the highest percent of organic matter (75\% manure), resulting into lower values for APA, DAC and NF from the 150 DAP on. That worse performance of the plants grown of T3 may have been by the incidence of disease which provoked the death of some plants. So, T3 also presented the smallest dry biomass both for root and for shoot (Table 5).

Plants of T8 followed by those of T5, T7 and T1 presented the greatest results for root dry biomass. Those results can explain the high potential of adaptation and development of this species under the nutrients obtained on the substrates (Table 1) with a good response to the growth of the roots. It is possible for zinc to be in its ideal range acting as a catalyzer in the synthesis of indolilacetic acid provoking an increase of the auxin level in the tissues which made the greatest results for the root dry biomass viable. Increased values for the root dry matter mass are indicators of greater percentage of survival in the field, since that the presence of fibrous roots allows greater capacity for them to keep themselves in growth and formation of new, more active roots, enabling increased tolerance under adverse conditions. On the basis of this statement, one can predict that the seedlings which presented the highest means of root dry matter are more propitious to survive when taken to the field. The shoot dry matter should be taken into consideration since it indicates the roughness of a seedling, the larger, more rougher it will be. Taking as a basis this statement, it is possible for the seedlings produced with substrates $\mathrm{T} 5, \mathrm{~T} 8, \mathrm{~T} 7, \mathrm{~T} 2$ and $\mathrm{T} 1$ be rougher than the other.

\section{CONCLUSIONS}

1. Açaí seeds considered large present greater germination percent in relation to small seeds and the substrate sand provides greater germination percent of seeds.

2. Substrates composed by $75 \%$ (soil + sand $-\mathrm{T} 1$ ) $+25 \%$ of manure (T5) and by $75 \%$ (soil + sand $-\mathrm{T} 1$ ) $+25 \%$ of carbonized rice hull (T8) provided better development of açai seedlings.

\section{ACKNOWLEDGMENTS}

The authors are greatly thankful to CNPq, CAPES and FEMARH for financial support.

\section{REFERENCES}

[1] ARAÚJO, W.F.; JÚNIOR, A.S. A.; MEDEIROS, R.D.; SAMPAIO, R.A. 2001. Precipitação pluviométrica mensal provável em Boa Vista, Estado de Roraima, Brasil. Revista Brasileira de Engenharia Agrícola e Ambiental, 5(3):563-567.

[2] BRAHM, R. Ü. et al. Avaliação do efeito de diferentes substratos sobre o desenvolvimento de Euterpe Edulis (Mart.) e Roystonea regia (Kunth). 2013. Revista Brasileira de Agroecologia, 8(2):148-160.

[3] BECKMANN-CAVALCANTE, M. Z. et al. Temperatura, escarificação mecânica e substrato na germinação de sementes das palmeiras juçara e açaí. 2012. Revista Brasileira Ciências Agrárias, 7(4):569-573.

[4] BENTES, J.G.; IRIARTE MARTEL, J.H. 2010. Produção de mudas de açaí em diferentes substratos e tempo de despolpamento. In: XIX Jornada de Iniciação Científica PIBIC INPA-CNPq/FAPEAM, 2010, Manaus. Disponível em: http://pibic.inpa.gov.br/agrarias. Acessado em: 19 jun.2012.

[5] BOVI, M. L. A. 1993. Palmito pupunha: Informações básicas para o cultivo. In: Encontro sobre produção de palmito. Piracicaba, CALQ, p.12-23.

[6] CARVALHO, N. M.; NAKAGAWA, J. 2012. Sementes: Ciência tecnologia e produção. 5.ed. Jaboticabal: FUNEP, $590 \mathrm{p}$.

[7] CHAGAS, E. A.; RIBEIRO, M. I. G.; SOUZA, O.M.; SANTOS, V. A.; LOZANO, R. M. B.; LIMA, C. G. B. 2013. Alternatives substrates for production of seedlings camu-camu. Revista de Ciências Agrárias / Amazonian Journal of Agricultural and Environmental Sciences, 56:6-12. 
[8] CLEMENT, C. R. 1995. Growth and analysis of pejibaye (Bactris gasipaes Kunth, Palmae) in Hawaii. 221 p. (Tese Doutorado), University of Hawaii, Honolulu.

[9] FERREIRA, D. F. 2011. Sisvar: a computer statistical analysis system. Ciência e Agrotecnologia, 35(6):1039-1042.

[10] FILHO, S. M. et al. 2007. Diferentes substratos afetando o desenvolvimento de mudas de palmeiras. Revista Ceres, $311(54): 80-86$.

[11] FONTENELLE, A. C. F.; ARAGÃO, W. M.; RANGEL, J. H. A. 2007. Biometria de frutos e sementes de Desmanthus virgatus (L) Willd nativas de Sergipe. Revista Brasileira de Biociências, 1(5):252-254.

[12] GAMA, J. S. N. et al. 2010. Temperaturas e substratos para germinação e vigor de sementes de Euterpe oleracea Mart. Revista Ciência Agronômica, 41(4): 664-670.

[13] GONÇALVES, J. L. M. et al. 2000. Produção de mudas de espécies nativas: substrato, nutrição, sombreamento e fertilização. In: GONÇALVES, J. L. M.; BENEDETTI, V. (Ed.). Nutrição e fertilização florestal. Piracicaba: IPEF:309-350.

[14] KLEIN, J. et al. 2007. Efeito do tamanho da semente na emergência e desenvolvimento inicial de mudas de pitangueira (Eugenia uniflora L.). Revista Brasileira de Biociências, 5(2):861-863.

[15] LIMA, R. V.; LOPES, J. C.; COELHO, R. I. 2007. Germinação de sementes de urucu em diferentes temperaturas e substratos. Ciência e Agrotecnologia, 31(4):1219-1224.

[16] MARTINS FILHO, S. et al. 2007. Diferentes substratos afetando o desenvolvimento de mudas de palmeiras. Revista Ceres, 54(311):80-86.

[17] MATHEUS, M. T.; LOPES, J. C. 2007. Morfologia de frutos, sementes e plântulas e germinação de sementes de Erythrina variegata L. Revista Brasileira de Sementes, 29(3): 8-15.

[18] PARENTE, V. M.; OLIVEIRA JÚNIOR, A. R.; COSTA, A. M. 2013. Palmito de pupunheira; potencialidades regionais; estudo de viabilidade econômica. <http://www.suframa.gov.br/publicações/proj pot regionais/sumario/palmito.pdf>. 22 Set 2013.

[19] PIVETTA, K. F. L.; BARBOSA, J. G.; ARAÚJO, E. F. 2007. Propagação de palmeiras e strelitzia. In: Barbosa, J. G. (Ed.). Propagação de plantas ornamentais. Viçosa, MG: UFV, p.39-67.

[20] RODRIGUEZ, C. A.; CHAGAS, E. A.; PANDURO, M. P.; SORIA, D. G.; SANCHEZ-CHOY, J.; LOZANO, R. M. B.; SALDANA, G. R. 2013. Producción de plantas de camu camu con diferentes sustratos orgánicos en camas de vivero convencional. Scientia Agropecuaria, 4: 321-324.

[21] SANTOS, H. R. B. et al. 2012. Morfometria de sementes de pinhão manso (Jatropha curcas L.). Scientia Plena, 8(4):232-235.

[22] SILVA, K. S. et al. 2010. Influência do tamanho da semente na germinação e vigor de mudas de jaqueira (Artocarpus heterophyllus Lam.). Revista Verde, 5(4):217-221.

[23] TAVARES, A. R. et al. 2008. Jussara palm seed germination under different hade levels. Horticultura Brasileira, 26(4):492-494.

[24] TEDESCO, M.J.; GIANELLO, C. e BISSANI, C.A. 1995. Análise de solo, plantas e outros materiais - 2 ed. Porto Alegre: Departamento de Solos da UFRGS, 174p. (Boletim Técnico de Solos, 5)

[25] VENDRAMIN, D. W.; CARVALHO, R I. N. 2013. Qualidade fisiológica de sementes de pitangueira (Eugenia uniflora ( L.) (Myrtaceae). Estudos Biologicos, 35(84):59-65.

[26] WELTER, M. K.; CHAGAS, E. A.; MELO, V.F.; CHAVES, D.B. 2014. Initial Growth of Açaí Seedlings in Function of Basalt Powder Doses. International Journal of Agriculture Innovations and Research, 3:1823. 